\title{
Iron and glutathione at the crossroad of redox metabolism in neurons
}

\author{
PAULA ARACENA, PABLA AGUIRRE, PABLO MUÑOZ and MARCO T. NÚÑEZ
}

Department of Biology, Faculty of Sciences and Cell Dynamic and Biotechnology Research Center, Universidad de Chile, Santiago, Chile

\begin{abstract}
Neurons, as non-dividing cells, encounter a myriad of stressful conditions throughout their lifespan. In particular, there is increasing evidence that iron progressively accumulates in the brain with age and that ironinduced oxidative stress is the cause of several forms of neurodegeneration. Here, we review recent evidence that gives support to the following notions: 1) neuronal iron accumulation leads to oxidative stress and cell death; 2) neuronal survival to iron accumulation associates with decreased expression of the iron import transporter DMT1 and increased expression of the efflux transporter IREG1; and 3) the adaptive process of neurons towards iron-induced oxidative stress includes a marked increase in both the expression of the catalytic subunit of gamma glutamate-cysteine ligase and glutathione. These findings may help to understand aging-related neurodegeneration hallmarks: oxidative damage, functional impairment and cell death.
\end{abstract}

Key terms: neurons, iron metabolism, iron accumulation, oxidative stress, glutathione metabolism, neurodegeneration

The Janus face of iron in cell function: A link to neurodegeneration

Iron, in virtue of its ability to participate directly as a donor or acceptor in electrontransfer reactions, is an essential trace element for cell function. This property makes iron the most common cofactor within the oxygen handling biological machinery $(4,8)$. Additional roles for iron have been described in neurons, such as its participation in myelin synthesis (10) and neurotransmitter metabolism (30). However, the very property that enables iron to participate in oxygen metabolism explains its potential damaging effects: if not handled properly by the cell, iron interacts with molecular oxygen, generating reactive oxygen species (ROS) through Haber-Weiss and Fenton reactions (18). As reviewed elsewhere, uncontrolled ROS production leads to oxidative damage of cellular components, a condition termed 'oxidative stress' (14).
Recent evidence highlights the relevance of iron metabolism in neurodegeneration. Some genetic neurodegenerative diseases have been linked to mutations in the ferritin light chain gene (9) and the pantothenate kinase gene (20), demonstrating a direct relationship between mutations in iron handling proteins and neurodegenerative processes. Similarly, postmortem studies have shown increased iron accumulation in the substantia nigra pars compacta (SNpc) of Parkinson disease (PD) patients (16). With age, iron accumulates in redoxsensitive tissues such as substantia nigra even in normal individuals (42) (Fig. 1). Additionally, age-related increases in the iron content of different areas of the brain were demonstrated in rat and monkey (19, 36).

Mounting evidence indicates that neurons from Alzheimer disease (AD) brains are subjected to a high oxidative load (6). In addition, in PD models a link between iron deregulation and oxidative 
stress has been suggested (3). Data from our group indicate that iron accumulation leads to increase oxidative stress and cell death in cultured neuroblastoma cells and hippocampal neurons (2) (Fig. 2). All together, these findings suggest that iron accumulates and causes oxidative damage in selected brain areas. In the following sections, we review the available information about iron metabolism and iron-related oxidative stress in neuronal tissue. We also describe evidence obtained by our group suggesting a link between iron and glutathione metabolism.

Iron accumulation: Roles of the iron transporters DMT1 and Ireg 1

The activities of the iron transporters DMT1 and Ireg1 (also termed ferroportin 1 and MTP1) determine iron movements into or out of cells. DMT1 mediates iron transport into cells by an electrogenic mechanism that involves the co-transport of $\mathrm{Fe}^{2+}$ and $\mathrm{H}^{+}$(2). Although DMT1 mRNA expression in neuronal tissue is down regulated by an increase in cellular iron content $(2,3,17,39$; reviewed in 25), there is no agreement about the specific mechanisms responsible for this regulation. DMT1 gene transcription produces four isoforms by alternative splicing of the $5^{\prime}$-end exons [exons $1 \mathrm{~A}$ or $1 \mathrm{~B}$ ] and of the 3'-end exons [exons 16 (or + IRE) or 16A (or -IRE)] (21). Expression of the +1A/+IRE isoform is particularly sensitive to cell iron levels, but the 1A/-IRE isoform also responds to iron changes, whereas the 1B/+IRE and 1B/-IRE isoforms do not respond. Thus, it is possible that the regulation of DMT1 expression involves two regulatory processes, one mediated by exon $1 \mathrm{~A}$, probably of transcriptional origin, and another mediated by exon 16 (+IRE), probably of transductional origin.
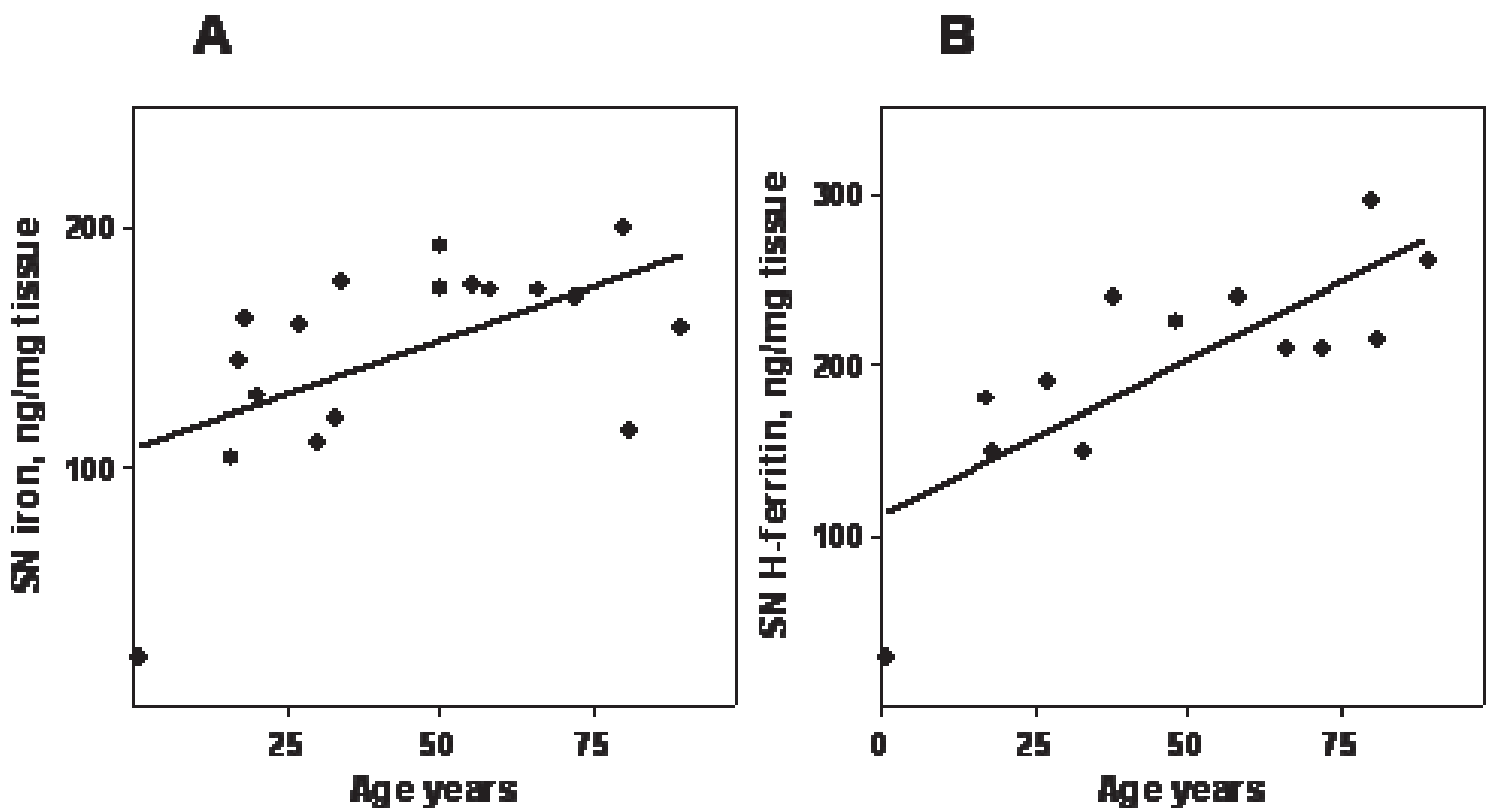

Figure 1. Iron accumulation in substantia nigra. Determination of total iron (A) and H-ferritin (B) in substantia nigra (SN) tissue from normal individuals. Total iron and $\mathrm{H}$-ferritin seem to increase markedly during the first 20-25 years of age, followed by a slower but sustained increase at later ages. Each point of the figure corresponds to one subject. Data were best fit to a linear regression model (total iron: $\mathrm{SN}$ iron $(\mathrm{ng} / \mathrm{mg}$ tissue $)=0.91 \mathrm{x}$ age $+107.70 ; \mathrm{R} 2: 0.31, \mathrm{P}: 0.016 ; \mathrm{H}-$ ferritin: $\mathrm{SN}$ ferritin $(\mathrm{ng} / \mathrm{mg}$ tissue $)=1.82 \mathrm{x}$ age $+111.90 ; \mathrm{R} 2: 0.62$, P: 0.001). (Adapted from figures 1 and 3 of reference 42, with permission from the publisher.) 

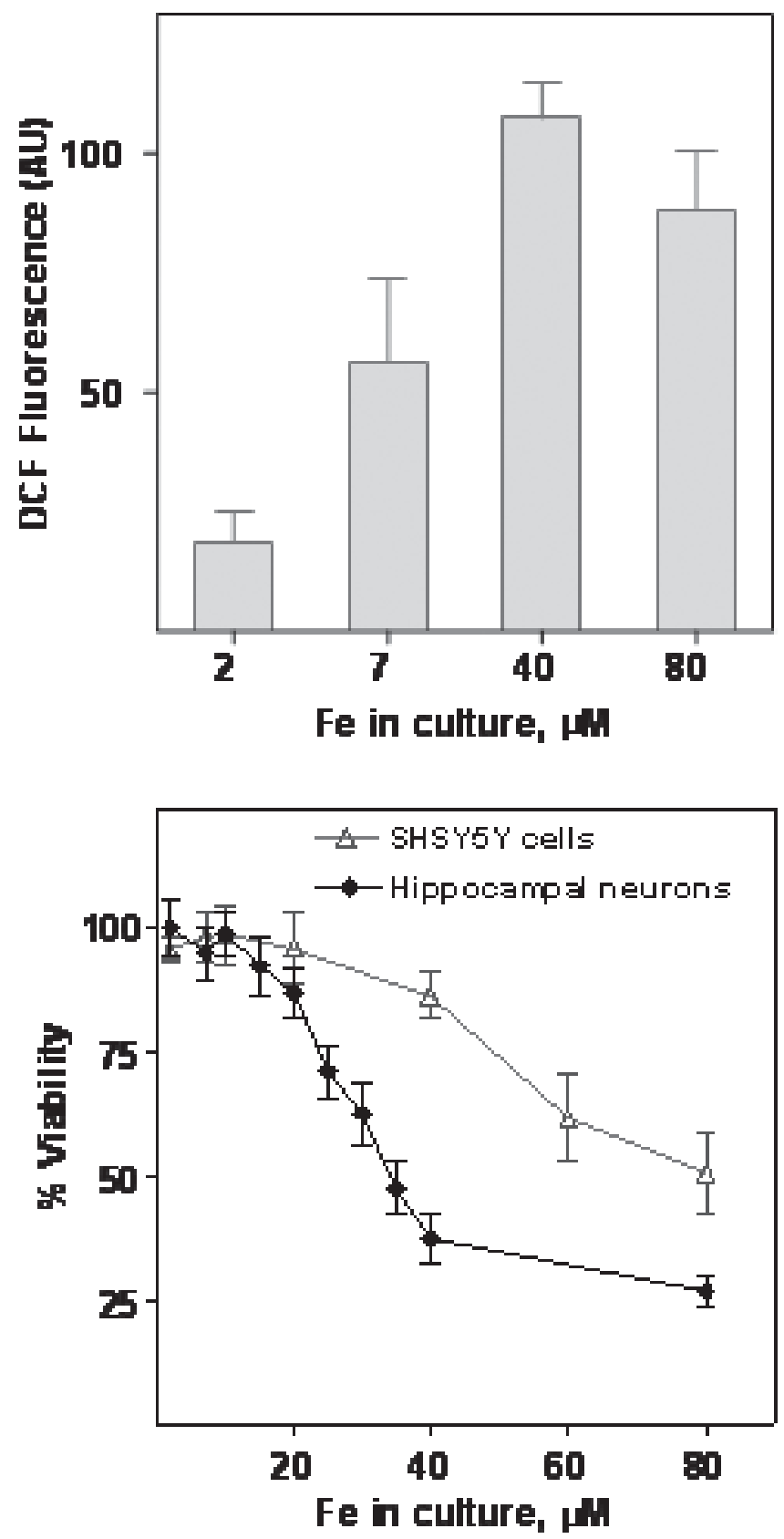

Figure 2. Iron-induced oxidative stress and cell death. A: iron accumulation induces ROS. SHSY5Y cells were grown in glass cover slips for 8 days in standard $5 \mu \mathrm{M}$ Fe media after which they were challenged for 2 days with $1.5,5,10,40$ or $80 \mu \mathrm{M}$ iron. The levels of ROS were determined by measuring 2',7'-dichlorofluorescein (DCF) fluorescence (34). Stabilization in cell ROS was apparent at high iron concentrations, evidencing an adaptative response (adapted from reference 31, with permission from the publisher). B: iron-induced cell death. SH-SY5Y cells were grown in 96plate wells for 8 days in standard $5 \mu \mathrm{M}$ Fe media as described in the Methods, after which they were challenged with varied concentrations of iron and the culture continued for 2 days. Cell viability at the end of the culture period was determined by the MTT method. Each individual point was done in triplicates. Shown is one of three similar experiments. Decay in cell viability was apparent with both increased iron concentration and with time of incubation (adapted from reference 31 ). 
Ireg1 is the only member of the SLC40 family of transporters and the first reported protein that mediates the exit of iron from cells. Structural modeling indicates an Ireg1 membrane topology of nine transmembrane domains with a cytoplasmic $\mathrm{N}$-terminal domain and an extracellular C-terminal region (reviewed in 26). This protein is expressed mainly in enterocytes and macrophages, but the presence of Ireg1 also has been described in neurons, glioma cells and astrocytes $(5,13,22)$. In enterocytes, Ireg1 is responsible for iron efflux during the process of intestinal iron absorption, while in Kupffer cells Ireg1 mediates iron export for reutilization by the bone marrow (11). The mechanism underlying regulation of Ireg1 expression is unknown, but it is clearly cell-specific; in enterocytes, iron deficiency induces Ireg1 expression (27), whereas in macrophages iron deficiency decreases Ireg1 expression (7). In a recent study, we reported that SH-SY5Y neuroblastoma that survived conditions of iron overload display an adaptive response consisting of decreased synthesis of DMT1 and increased synthesis of Ireg1 (2) (Fig. $3)$. Ireg 1 expression correlates with iron content in SH-SY5Y and hippocampal cells; similarly, there is a correlation between Ireg1 expression and the rate of iron efflux (2). Thus, one of the clues of neuronal survival to iron overload seems to be the coordinated regulation of both influx and efflux iron transporters.

\section{Glutathione: The main antioxidant molecule in neurons}

Neuronal antioxidant defenses rely mainly on the cellular levels of reduced glutathione (GSH) $(15,28)$. Elevated GSH levels in hippocampus and midbrain were reported in AD (1), an indication that AD neurons may be over-reacting to an oxidative load. Similarly, decreased activity of antioxidant enzymes occurs in AD brains (32), an indication that the normal handling of GSH may be altered in these cells. A $30-40 \%$ decrease in GSH concentrations, without a corresponding increase in the levels of oxidized GSH (GSSG), was reported in PD brains (33). In addition, GSH levels in PD are specifically decreased in $S N p c$ without a concomitant increase in the levels of GSSG (37), and the decrease in GSH content correlates with the severity of neurodegeneration (34). Thus, substantial evidence points to profound changes in GSH metabolism in neurodegenerative processes.

\section{DMT1}
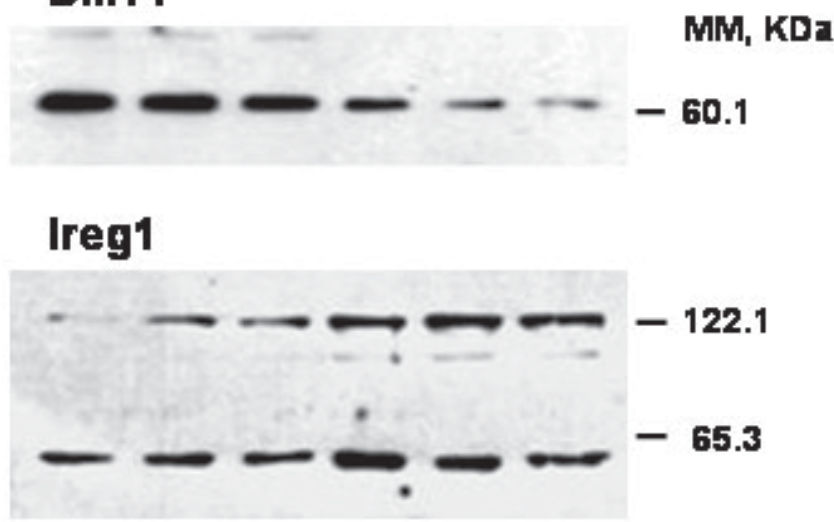

$\begin{array}{lllllll}\mathrm{Fe}, \mu \mathrm{M} & 1.5 & 5 & 10 & 20 & 40 & 80\end{array}$

Figure 3. Regulation of iron transporters DMT1 and Ireg1 by iron accumulation. DMT1 and Ireg 1 from SH-SY5Y cells cultured for 2 days with different iron concentrations were determined by Western blot. A decrease in DMT1 expression and an increase in Ireg1 expression was observed in the 1.5-80 $\mu \mathrm{M}$ Fe range. In Ireg1 determination, bands of 65.3 and $122.1 \mathrm{KDa}$, corresponding to putative monomers and dimers, were evident (adapted from reference 3 ). 
Progressive iron accumulation induces a biphasic change in GSH levels

SH-SY5Y cells cultured in $1.5 \mu \mathrm{M}$ iron present basal GSH levels, but increasing iron from 1.5 to $5 \mu \mathrm{M}$ results in a marked increase in GSH levels (Fig. 4). Increased GSH levels are due to increased synthesis, as determined by the inhibitory effect of the GSH synthesis inhibitor L-buthionine sulfoximine (31). Further increases in iron concentration lead to significant reductions in GSH content. Thus, iron accumulation sequentially induces an increase and then a decrease in GSH content. Since treatment of cells with iron in the $40-80 \mu \mathrm{M}$ range induces significant cell death (31), the adaptation of cells surviving a high iron offer was further studied. To that end, cells that survived the initial onslaught caused by high iron offer were kept in culture for two additional days prior to GSH evaluation. Under these conditions, the cells presented important increases in GSH levels at 40 and
$80 \mu \mathrm{M} \mathrm{Fe}$ in the culture media (Fig. 4). This increase in GSH levels in surviving cells can be viewed as an adaptive response to iron-induced oxidative stress and underlines the particular relevance of GSH in the antioxidant response.

Neuronal oxidative balance must be regulated; therefore, compensatory mechanisms are expected to surge upon oxidative stress. In the case of AD, this is not entirely clear since both a decrease (24) and an increase (7) in GSH content have been reported. Since under our conditions increased GSH was a consequence of increased cellular iron, we hypothesize that, compared to normal neurons, AD neurons have undergone increased iron accumulation that results in excessive GSH synthesis. Indeed, increased GSH synthesis may correspond to late steps in AD where major compensatory changes in the reduction state of affected neurons have been reported $(35,43)$.

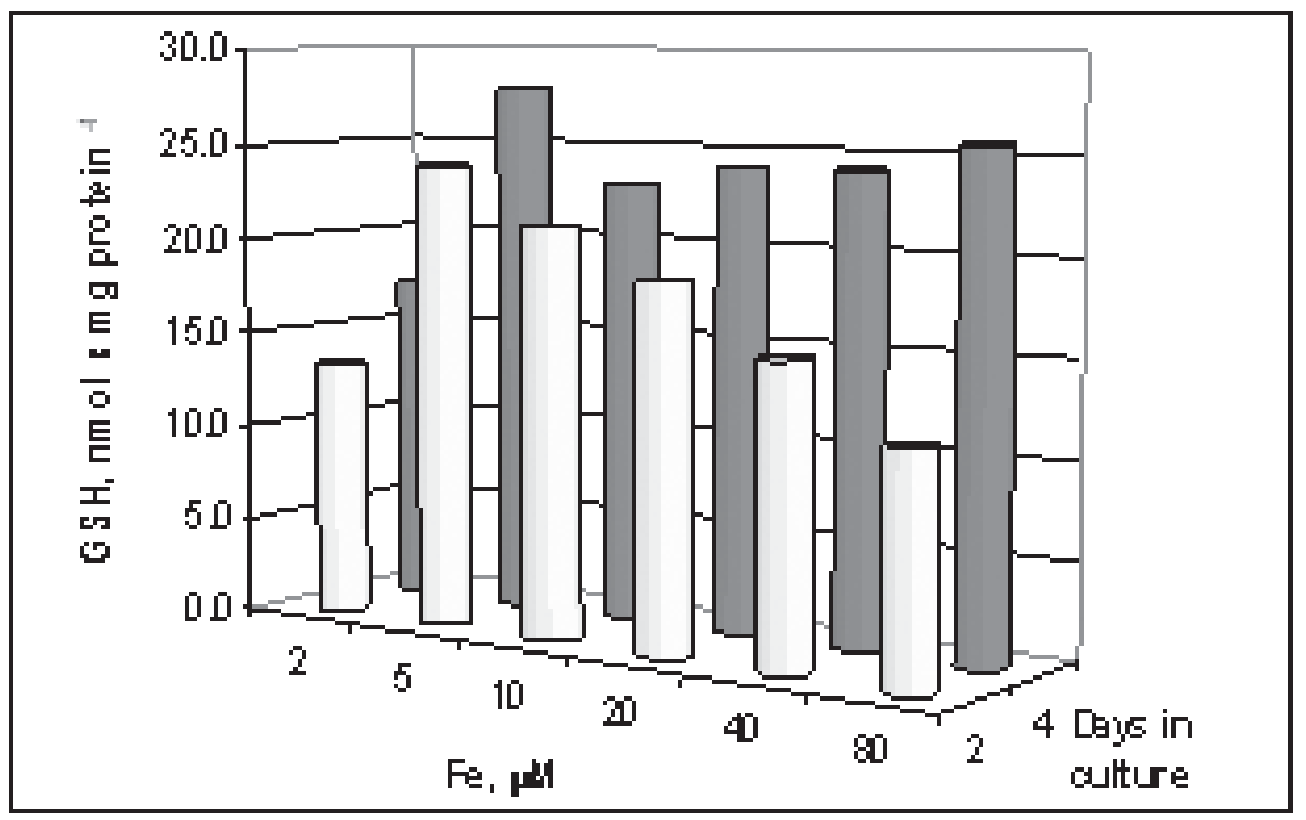

Figure 4. Iron induction of GSH synthesis. A. SH-SY5Y cells were cultured for 8 days in standard culture medium and then for 2 or 4 days in media with $1.5,5,10,20,40$ or $80 \mu \mathrm{M}$ iron. Cell extracts were prepared and GSH levels were determined as described (34). Note the inverse relationship between iron and GSH levels in the range $20-80 \mu \mathrm{M} F e$ at 2 days of culture. When compared with the 2 -day values, a significant increase in GSH content $(*: p<0.001)$ was observed at 4 days for the 40 and $80 \mu \mathrm{M}$ Fe conditions. Data represent means of 4 (2 days) or 3 (4 days) independent determinations. 
The GSH content increase correlates with GCL expression

Glutamate cysteine ligase (GCL) is the ratelimiting enzyme for GSH synthesis (12). GCL is a heterodimer composed by a catalytic or heavy subunit (GCLC) and a modulatory or light subunit (GCLM), which are encoded by different genes. Both genes display upstream regions with antioxidant response elements, AREs, also known as electrophilic response elements $(9,38,40)$. Both Nrf2 and c-Jun transcription factors are involved through their AREs in the upregulation of the GCLC gene in human hepatoblastoma cells (23). The possibility that iron-induced oxidative stress might up- regulate GCLC or GCLM expression in SHSY5Y cells was explored (Fig. 5). After two days of challenging SH-SY5Y cells with $1.5,7$ or $80 \mu \mathrm{M}$ iron, two- and threefold increases in the expression of the catalytic GCLC subunit mRNA were apparent at 7 and $80 \mu \mathrm{M}$ iron. On the contrary, no significant changes in expression of the GCLM modulatory subunit were found. It was recently shown that hemin treatment of SH-SY5Y cells leads to Nrf2 nuclear translocation and to up-regulation of ARE-dependent oxidativestress related enzymes (29). Therefore, it is likely that the oxidative stress induced by iron overload caused activation of Nrf2 and increased expression of the GCLC subunit.
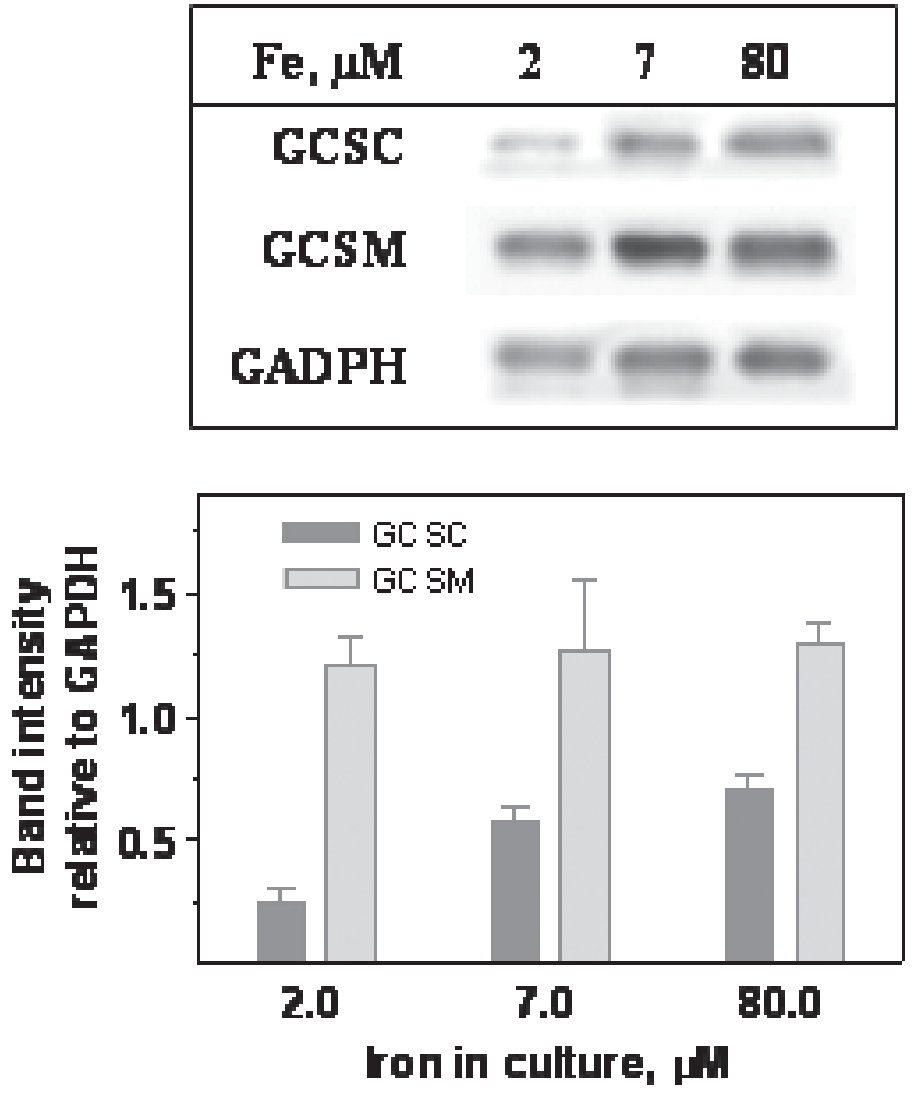

Figure 5. RT-PCR analysis of GCLC and GCLM expression. mRNA expression of the catalytic (GCLC) and regulatory (GCLM) sub-units of $\gamma$-glutamate cysteine ligase were determined by RTPCR of total RNA obtained from cells cultured with varied concentrations of iron for 2 days. GAPDH mRNA expression was used as an internal loading standard. The lower panel shows densitometry quantification of the RT-PCR bands normalized to GADPH expression. Mean \pm SD of 2 determinations. Iron promoted a 2.9 -fold increase in the mRNA of the GCSC subunit, while no significant change in the GCSM subunit was apparent. 


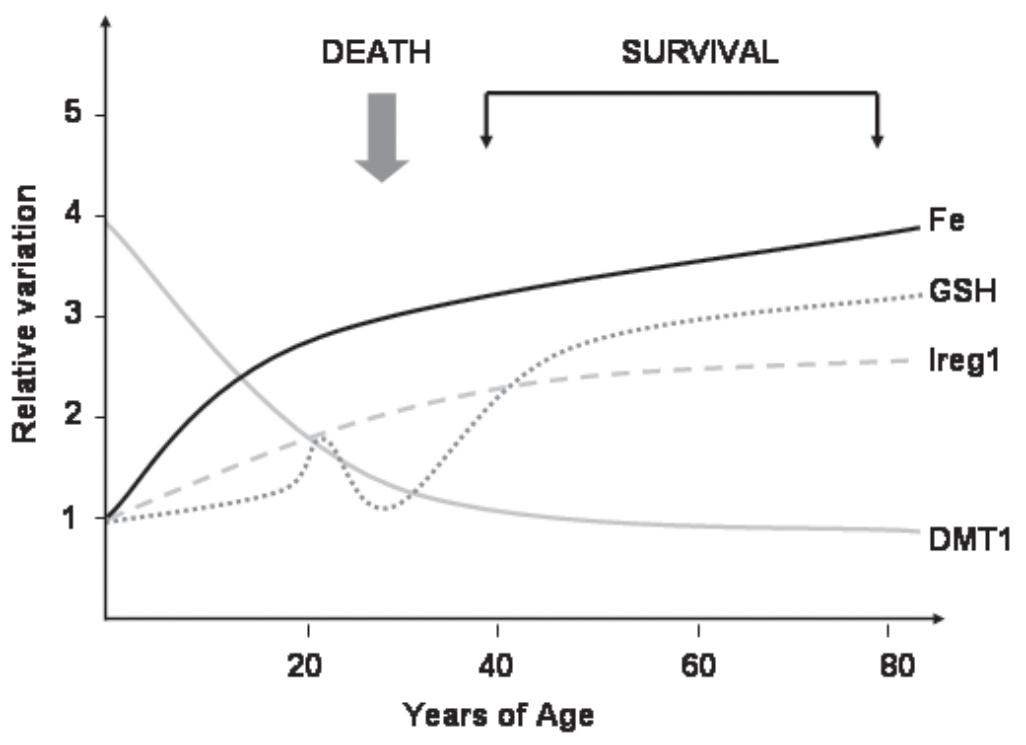

Figure 6. Hypothetical relationship of iron and GSH level during lifespan. The model represents the hypothetical variations in iron, GSH, DMT1 and Ireg1 in neurodegeneration-prone neurons during a lifespan of 80 years. Total iron content was derived from data in figure 1 . The hypothetical variations in the transporters DMT1 and Ireg1 were obtained from figure 3 and reference 14, in which iron accumulation induces up-regulation of Ireg1 and down-regulation of DMT1. The curve of GSH variation in time was derived from data in figure 4 that describes changes in GSH levels as a function of iron accumulation. GSH variations are shown as an initial increase followed by a decrease and, later, by a sustained increase in GSH. An event of massive cell death was tentatively located to a time when GSH may become critically low.

Concluding remarks: A model for the time course changes of neuronal iron and GSH levels during a lifespan

During the last few years, mounting evidence has been obtained indicating a strong relationship between iron accumulation, oxidative stress and neurodegeneration. A hypothetical time progression chart, describing changes in iron, GSH, DMT1 and Ireg1 levels in neurodegeneration-prone neurons during the human lifetime, is depicted in figure 6. Iron increases markedly during the initial 25 years of age. As a response to the initial iron accumulation, expression of DMT1 decreases and expression of Ireg1 increases. During this period, GSH levels present a biphasic response: an initial increase due to increased synthesis is followed by a decrease due to increased consumption. The decrease in GSH levels accompanied by the increased iron content result in oxidative conditions leading to cell death. Cells that adapt to the redox challenge enter a metastable condition characterized by a persistent pattern of iron accumulation accompanied by increasing levels of GSH.

\section{ACKNOWLEDGEMENTS}

This work was supported by grant P99-031 from the Millennium Scientific Initiative and by grant 1040448 from Fondo Nacional de Ciencia y Tecnología (FONDECYT) Santiago, Chile.

\section{REFERENCES}

1. ADAMS JD JR, KLAIDMAN LK, ODUNZE IN, SHEN HC, MILLER CA (1991) Brain levels of glutathione, glutathione disulfide, and vitamin E. Mol Chem Neuropathol 14: 213-226

2. AGUIRRE P, MENA N, TAPIA V, ARREDONDO M, NÚÑEZ MT (2005) Iron homeostasis in neuronal cells: a role for IREG1. BMC Neurosci 6: 3 
3. ANDERSEN JK (2004) Iron dysregulation and Parkinson's disease. J Alzheimer's Dis 6: S47-52

4. BEARD J (2003) Iron deficiency alters brain development and functioning. J Nutr 133: 1468S$1472 \mathrm{~S}$

5. BURDO JR, MENZIES SL, SIMPSON IA, GARRICK LM, GARRICK MD, DOLAN KG, HAILE DJ, BEARD JL, CONNOR JR (2001) Distribution of divalent metal transporter 1 and metal transport protein 1 in the normal and Belgrade rat. J Neurosci Res 66: 1198-1207

6. CASADESUS G, SMITH MA, ZHU X, ALIEV G, CASH AD, HONDA K, PETERSEN RB, PERRY G. (2004) Alzheimer disease: evidence for a central pathogenic role of iron-mediated reactive oxygen species. J Alzheimer's Dis 6: 165-169

7. CHO HY, REDDY SP, DEBIASE A, YAMAMOTO M, KLEEBERGER SR (2005) Gene expression profiling of NRF2-mediated protection against oxidative injury. Free Radic Biol Med 38: 325-343

8. CRICHTON RR, WARD RJ (1992) Iron metabolism New perspectives in view. Biochemistry 31: 1125511264

9. CROMPTON DE, CHINNERY PF, FEY C, CURTIS AR, MORRIS CM, KIERSTAN J, BURT A, YOUNG F, COULTHARD A, CURTIS A, INCE PG, BATES D, JACKSON MJ, BURN J (2002) Neuroferritinopathy: A window on the role of iron in neurodegeneration. Blood Cells Mol Dis 29: 522-531

10. DEREGNIER R, NELSON C, THOMAS $\mathrm{K}$, WEWERKA S, GEORGIEFF M (2000) Neurophysiologic evaluation of auditory recognition memory in healthy newborn infants and infants of diabetic mothers. J Pediatr 137: $777-784$

11. DEVALIA V, CARTER K, WALKER AP, PERKINS SJ, WORWOOD M, MAY A, DOOLEY JS (2002) Autosomal dominant reticuloendothelial iron overload associated with a 3-base pair deletion in the ferroportin 1 gene (SLC11A3). Blood 100: 695-697

12. DICKINSON DA, LEVONEN AL, MOELLERING DR, ARNOLD EK, ZHANG H, DARLEY-USMAR VM, FORMAN HJ (2004) Human glutamate cysteine ligase gene regulation through the electrophile response element. Free Radic Biol Med 37: 1152-1159

13. DIPATTI MC, PERSICHINI T, MAZZONE V, POLTICELLI F, COLASANTI M, MUSCI G (2004) Interleukin-1beta up-regulates iron efflux in rat C6 glioma cells through modulation of ceruloplasmin and ferroportin-1 synthesis. Neurosci Lett 363: 182-186

14. DROGE W (2003) Oxidative stress and aging. Adv Exp Med Biol 543: 191-200

15. DRUKARCH B, SCHEPENS E, JONGENELEN CA, STOOF JC, LANGEVELD CH (1997) Astrocytemediated enhancement of neuronal survival is abolished by glutathione deficiency. Brain Res 770: 123-130

16. GOTZ ME, DOUBLE K, GERLACH M, YOUDIM MB, RIEDERER P (2004) The relevance of iron in the pathogenesis of Parkinson's disease. Ann NY Acad Sci 1012: 193-208

17. GUNSHIN H, MACKENZIE B, BERGER UV, GUNSHIN Y, ROMERO MF, BORON WF, NUSSBERGER S, GOLLAN JL, HEDIGER MA (1997) Cloning and characterization of a mammalian proton-coupled metal-ion transporter. Nature 388: 482488

18. HALLIWELL B, GUTTERIDGE JMC (1999) Oxidative stress: Adaptation, damage, repair and death. In: Free Radicals in Biology and Medicine. 3rd Ed. Oxford, UK: Oxford University Press. pp: 246-350
19. HARDY PA, GASH D, YOKEL R, ANDERSEN A, AI Y, ZHANG Z (2005) Correlation of R2 with total iron concentration in the brains of rhesus monkeys. J Magn Reson Imaging 21: 118-127

20. HAYFLICK SJ (2003) Unraveling the HallervordenSpatz syndrome: pantothenate kinase-associated neurodegeneration is the name. Curr Opin Pediatr 15: 572-527.

21. HUBERT N, HENTZE MW. (2002) Previously uncharacterized isoforms of divalent metal transporter (DMT)-1: Implications for regulation and cellular function. Proc Natl Acad Sci USA 99: 12345-12350

22. JEONG SY, DAVID S (2003) Glycosylphosphatidylinositol-anchored ceruloplasmin is required for iron efflux from cells in the central nervous system. J Biol Chem 278: 27144-27148

23. JEYAPAUL J, JAISWAL AK (2000) Nrf2 and c-Jun regulation of antioxidant response element (ARE)mediated expression and induction of gammaglutamylcysteine synthetase heavy subunit gene. Biochem Pharmacol 59: 1433-1439

24. LIU H, WANG H, SHENVI S, HAGEN TM, LIU RM (2004) Glutathione metabolism during aging and in Alzheimer disease. Ann N Y Acad Sci 1019: 346-349

25. MACKENZIE B, HEDIGER MA (2004) SLC11 family of $\mathrm{H}+$-coupled metal-ion transporters NRAMP1 and DMT1. Pflugers Arch - Eur J Physiol 447: 571-579

26. MCKIE AT, BARLOW DJ (2004) The SLC40 basolateral iron transporter family (IREG1/ ferroportin/ MTP1). Pflugers Arch - Eur J Physiol 447: 801-806

27. MCKIE AT, MARCIANI P, ROLFS A, BRENNAN K, WEHR K, BARROW D, MIRET S, BOMFORD A, PETERS TJ, FARZANEH F, HEDIGER MA, HENTZE MW, SIMPSON RJ (2000) A novel duodenal ironregulated transporter, IREG1, implicated in the basolateral transfer of iron to the circulation. Mol Cell 5 299-309

28. MEISTER A (1983) Selective modification of glutathione metabolism. Science 220: 472-477

29. NAKASO K, YANO H, FUKUHARA Y, TAKESHIMA T, WADA-ISOE K, NAKASHIMA K (2003) PI3K is a key molecule in the Nrf2-mediated regulation of antioxidative proteins by hemin in human neuroblastoma cells. FEBS Lett 546: 181-184

30. NELSON C, ERIKSON K, PINERO D, BEARD JL (1997) Alterations in dopamine metabolism in iron deficient rats. J Nutr 12: 2282-2288

31. NÚÑEZ MT, GALLARDO V, MUÑOZ P, TAPIA V ESPARZA A, SALAZAR J, SPEISKY H (2004) Progressive iron accumulation induces a biphasic change in the glutathione content of neuroblastoma cells. Free Radic Biol Med 37: 953-960

32. OMAR RA, CHYAN YJ, ANDORN AC, POEGGELER B, ROBAKIS NK, PAPPOLLA MA (1999) Increased expression but reduced activity of antioxidant enzymes in Alzheimer's Disease. J Alzheimer's Dis 1: 39-145

33. PERRY TL, YONG VW (1986) Idiopathic Parkinson's disease, progressive supranuclear palsy and glutathione metabolism in the substantia nigra of patients. Neurosci Lett 67 269-274

34. RIEDERER P, SOFIC E, RAUSCH WD, SCHMIDT B, REYNOLDS GP, JELLINGER K, YOUDIM MB (1989) Transition metals, ferritin, glutathione, and ascorbic acid in parkinsonian brains. J Neurochem 52: 515-520

35. RUSSELL RL, SIEDLAK SL, RAINA AK, BAUTISTA JM, SMITH MA, PERRY G (1999) Increased neuronal glucose-6-phosphate dehydrogenase and sulphydryl levels indicate reductive compensation 
to oxidative stress in Alzheimer disease. Arch Biochem Biophys 370: 236-239

36. SHOHAM S, YOUDIM MB (2002) The effects of iron deficiency and iron and zinc supplementation on rat hippocampus ferritin. J Neural Transm 109: 1241-1256

37. SOFIC E, LANGE KW, JELLINGER K, RIEDERER P (1992) Reduced and oxidized glutathione in the substantia nigra of patients with Parkinson's disease. Neurosci Lett 142: 128-130

38. SOLTANINASSAB SR, SEKHAR KR, MEREDITH MJ, FREEMAN ML (2000) Multi-Faceted Regulation of $\gamma$-Glutamylcysteine Synthetase. J Cell Physiol 182: $163-170$

39. WANG XS, ONG WY, CONNOR JR (2003) Quinacrine attenuates increases in divalent metal transporter-1 and iron levels in the rat hippocampus, after kainate-induced neuronal injury. Neuroscience 120: $21-29$
40. YANG H, WANG J, HUANG Z, OU X, LU S (2001) Cloning and characterization of the 5'-flanking region of the rat glutamate-cysteine ligase catalytic subunit. Biochem J 357: 447-455

41. YANG F, WANG X, HAILE DJ, PIANTADOSI CA, GHIO AJ (2002) Iron increases expression of ironexport protein MTP1 in lung cells. Am. J. Physiol Lung Cell Mol Physiol 283: L932-L939

42. ZECCA L, GALLORINI M, SCHÜNEMANN V, ALFRED $X$, TRAUTWEIN, AX, GERLACH M, RIEDERER, P, VEZZONI P, TAMPELLINI D (2001) Iron, neuromelanin and ferritin content in the substantia nigra of normal subjects at different ages: Consequences for iron storage and neurodegenerative processes. J Neurochem 76: 1766-1773

43. ZHU X, RAINA AK, LEE HG, CASADESUS G, SMITH MA, PERRY G (2004) Oxidative stress signaling in Alzheimer's disease. Brain Res 1000: 32-39 